\title{
Sulfuretin protects against cytokine-induced $\beta$-cell damage and prevents streptozotocin-induced diabetes
}

\author{
Mi-Young Song ${ }^{1 *}$, Gil-Saeng Jeong ${ }^{2 *}$, \\ Kang-Beom Kwon ${ }^{3}$, Sun-O Ka ${ }^{1}$, Hyun-Young Jang ${ }^{1}$, \\ Jin-Woo Park ${ }^{1}$, Youn-Chul Kim ${ }^{4}$ and \\ Byung-Hyun Park ${ }^{1,5}$

\section{'Department of Biochemistry} \\ Medical School and Diabetes Research Center \\ Chonbuk National University \\ Jeonju 561-756, Korea \\ ${ }^{2}$ Zoonosis Research Center \\ ${ }^{3}$ Department of Physiology \\ School of Oriental Medicine \\ ${ }^{4}$ College of Pharmacy \\ Wonkwang University \\ Iksan 570-749, Korea \\ ${ }^{5}$ Corresponding author: Tel, 82-63-270-3139; \\ Fax, 82-63-274-9833; E-mail, bhpark@ chonbuk.ac.kr \\ *These authors contributed equally to this work. \\ DOI 10.3858/emm.2010.42.9.062
}

Accepted 7 June 2010

Available Online 27 July 2010

Abbreviations: EMSA, electrophoretic mobility shift assay; ROS, reactive oxygen species

\begin{abstract}
NF-kB activation has been implicated as a key signaling mechanism for pancreatic $\beta$-cell damage. Sulfuretin is one of the main flavonoids produced by Rhus verniciflua, which is reported to inhibit the inflammatory response by suppressing the NF-kB pathway. Therefore, we isolated sulfuretin from Rhus verniciflua and evaluated if sulfuretin could inhibit cytokine- or streptozotocin-induced $\beta$-cell damage. Rat insulinoma RINm5F cells and isolated rat islets were treated with IL-1 $\beta$ and IFN- $\gamma$ to induce cytotoxicity. Incubation of cells and islets with sulfuretin resulted in a significant reduction of cytokine-induced NF- $\mathrm{kB}$ activation and its downstream events, iNOS expression, and nitric oxide production. The cytotoxic effects of cytokines were completely abolished when cells or islets were pretreated with sulfuretin. The protective effect of sulfuretin was further demonstrated by normal insulin secretion of cytokine-treated islets in response to glucose. Treatment of mice with streptozotocin re-
\end{abstract}

sulted in hyperglycemia and hypoinsulinemia, which was further evidenced by immunohistochemical staining of islets. However, the diabetogenic effects of streptozotocin were completely prevented when mice were pretreated with sulfuretin. The anti-diabetogenic effects of sulfuretin were also mediated by suppression of NF-KB activation. Collectively, these results indicate that sulfuretin may have therapeutic value in preventing $\beta$-cell damage.

Keywords: cytokines; diabetes mellitus, experimental; NF-кB; Rhus verniciflua; streptozotocin; sulfuretin

\section{Introduction}

Type 1 diabetes mellitus is an autoimmune disease that causes selective destruction of insulin-producing $\beta$-cells in the islets of Langerhans. In early-stage disease, infiltration of inflammatory cells into the pancreatic islets can be observed histologically (Papaccio, 1993). These inflammatory cells produce and release cytokines, including IL-1 $\beta$, TNF- $\alpha$, and IFN- $\gamma$ (Hanafusa and Imagawa, 2008). Interleukin-1 $\beta$, alone or in combination with TNF- $\alpha$ or IFN- $\gamma$, upregulates iNOS and produces high levels of nitric oxide in the pancreatic islets (Cnop et al., 2005; Eizirik et al., 2009). Nitric oxide is produced by the oxidation of L-arginine to L-citrulline by nitric oxide synthase, and generation of excess nitric oxide may inhibit mitochondrial metabolism, protein modification, and DNA cleavage, any one of which could lead to impaired insulin secretion and $\beta$-cell death (Stadler et al., 1991; Corbett and McDaniel, 1992). Inhibition of iNOS activity by aminoguanidine or $N^{\mathrm{w}}$-nitro-L-arginine methyl ester protects islets against cytokine toxicity (Corbett and McDaniel, 1996; Kim et al., 2007b). Streptozotocin is a diabetogenic agent that is toxic to pancreatic $\beta$-cells and is commonly used in diabetes research (Szkudelski, 2001). Streptozotocin contains a nitroso moiety and releases nitric oxide during its metabolism (Kwon et al., 1994). In rodents, streptozotocin activates poly-ADP ribose polymerase, depletes cellular NAD and ATP, breaks DNA strands, and initiates $\beta$-cell necrosis (Yamamoto et al., 1981).

Nitric oxide production is regulated by transcription factors that bind to specific sites in the iNOS promoter. NF- $\mathrm{B}$, which can be activated by 
A

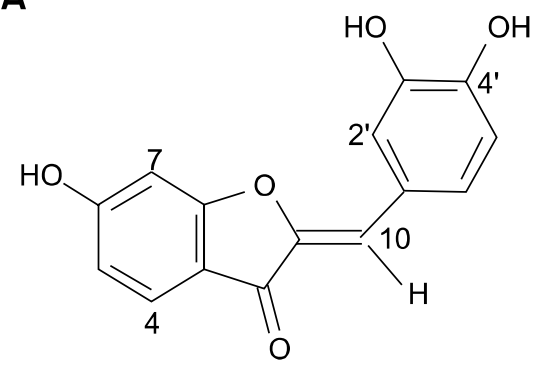

Sulfuretin (3', 4', 6'-trihydroxyaurone)
B

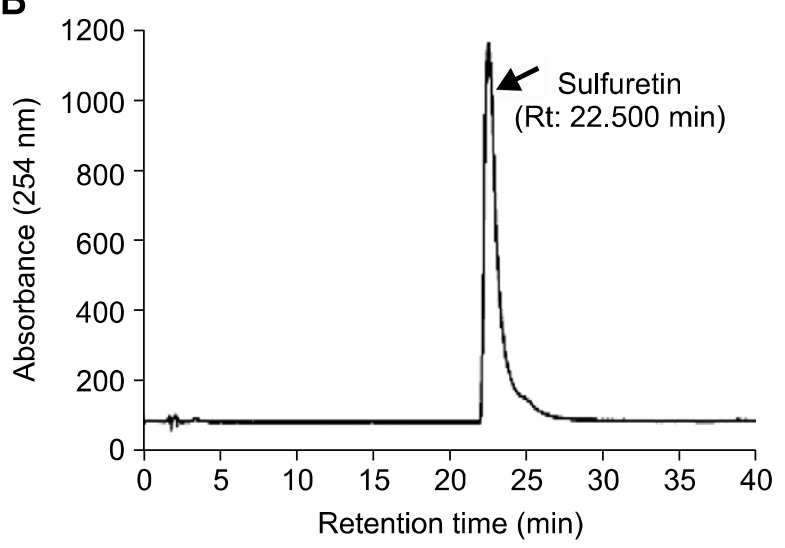

Figure 1. Chemical structure $(A)$ and HPLC chromatogram $(B)$ of sulfuretin

cytokines and streptozotocin, has been implicated as a key mediator in signaling iNOS induction (Heimberg, et al., 2001; Lv et al., 2009). NF-кB comprises a family of proteins, including p50, p52, p65 (RelA), p100, p105, and c-Rel (Pasparakis, 2009). When inactive, NF- $\kappa B$ is located in the cytosol and is complexed with the $I_{\kappa} \mathrm{B}$. Various inducers cause the complex to dissociate, presumably via $I_{\kappa} B$ phosphorylation. Released NF- $\mathrm{B} B$ then translocates to the nucleus, where it interacts with recognition sites to mediate gene transcription (Melloul, 2008). We and others have shown that $\mathrm{NF}-\kappa \mathrm{B}-$ dependent nitric oxide production is involved in the dysfunction and destruction of $\beta$-cells, suggesting nitric oxide involvement in autoimmune diabetes pathogenesis (Heimberg et al., 2001; Mabley et al., 2002; Kim et al., 2007b; Lv et al., 2008; Song et al., 2009).

Sulfuretin is a major flavonoid isolated from the heartwood of Rhus verniciflua, which has been used to reduce oxidative stress (Lee et al., 2002), platelet aggregation (Jeon et al., 2006), and mutagenesis (Park et al., 2004). A recent study has shown that $R$. verniciflua inhibits the inflammatory

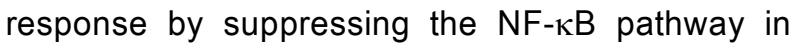
lipopolysaccharide-treated macrophages (Jung et al., 2007). However there is no report about the therapeutic efficacy of sulfuretin or $R$. verniciflua in the treatment of diabetes. Due to the critical role of the $N F-\kappa B$ pathway in $\beta$-cell damage, we isolated sulfuretin from $R$. verniciflua and examined the effectiveness of sulfuretin for preventing cytokine or streptozotocin-induced pancreatic $\beta$-cell damage using cultured RINm5F cells, isolated islets, and a streptozotocin-induced diabetes animal model.

\section{Results}

\section{Sulfuretin prevented cytokine-mediated cell death in RINm5F cells}

The chemical structure of sulfuretin $\left(3^{\prime}, 4^{\prime}, 6^{\prime}\right.$-trihydroxyaurone) is presented in Figure $1 \mathrm{~A}$. The appearance of a clean peak at retention time of $22.5 \mathrm{~min}$ in the HPLC chromatogram in Figure 1B indicates sulfuretin purity.

Untreated or RINm5F cells pretreated with sulfuretin for $3 \mathrm{~h}$ were exposed to cytokine for $48 \mathrm{~h}$, and viability was assessed using an MTT assay. Treatment with cytokine significantly reduced cell viability to $10.1 \pm 2.4 \%$ of the control (Figure $2 \mathrm{~A}$ ). Conversely, sulfuretin increased the viability of cytokine-treated RINm5F cells in a concentration-dependent manner. Treatment with sulfuretin alone did not affect cell viability at the concentrations used in this study.

Nitric oxide production was also evaluated. At 24 $\mathrm{h}$, control and cytokine-treated RINm5F cells generated $5.2 \pm 0.2 \mu \mathrm{M}$ and $25.6 \pm 0.5 \mu \mathrm{M}$ nitrite, respectively (Figure $2 \mathrm{~B}$ ). A concentration-dependent reduction in cytokine-mediated nitrite production was observed in RINm5F cells treated with cytokine plus sulfuretin, as near-complete inhibition of nitrite production was observed in cells that were pretreated with $100 \mu \mathrm{M}$ sulfuretin.

To investigate the regulatory effects of sulfuretin on nitric oxide production, we examined sulfuretin effects on cytokine-induced iNOS mRNA and protein expression using real time RT-PCR and Western blotting. Cytokine increased iNOS mRNA and protein levels (Figure 2B). However, when cells were treated with sulfuretin prior to cytokine treatment, mRNA and protein levels decreased in a concentration-dependent manner. Treatment with 
A

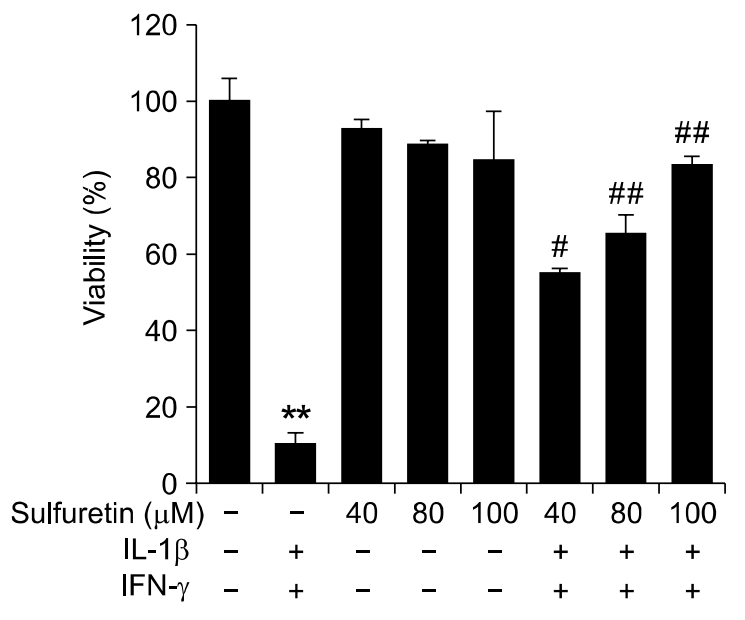

B
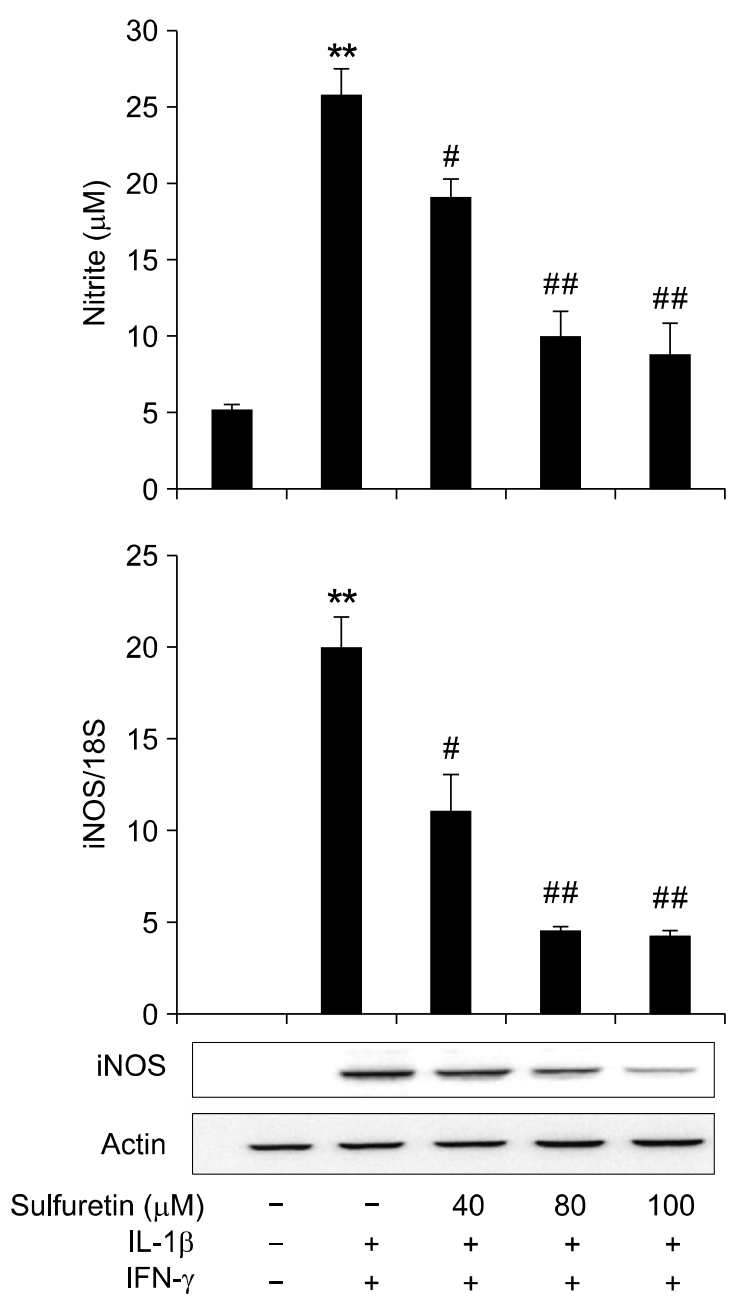

Figure 2. Sulfuretin prevents cytokine-induced cell death in RINm5F cells. (A) RINm5F cells were pretreated with the indicated concentrations of sulfuretin for $3 \mathrm{~h}$, and IL-1 $\beta(1 \mathrm{U} / \mathrm{ml})$ and IFN- $\gamma(100 \mathrm{U} / \mathrm{ml})$ were added for $48 \mathrm{~h}$. Cell viability was determined using an MTT assay. (B) RINm5F cells were pretreated with the indicated concentrations of sulfuretin for $3 \mathrm{~h}$, with subsequent addition of IL-1 $\beta$ and IFN- $\gamma$. Following $24 \mathrm{~h}$ incubation, the level of nitrite and iNOS mRNA and protein expression were determined. Each value is the mean \pm SEM of three independent experiments. ${ }^{* \star} P<0.01 \mathrm{vs}$. untreated control; $P<0.05,{ }^{\#} P<0.01$ vs. cytokine.

$100 \mu \mathrm{M}$ of sulfuretin markedly blocked iNOS expression.

\section{Sulfuretin suppressed the cytokine-induced NF-KB pathway in RINm5F cells}

$\mathrm{NF}-\mathrm{kB}$ has been implicated in the transcriptional regulation of cytokine-induced iNOS expression (Eizirik et al., 1996). Therefore, the effect of sulfuretin on the cytokine-stimulated translocation of $\mathrm{NF}-\mathrm{kB}$ from the cytosol to the nucleus in RINm5F cells was examined. Nuclear extracts from cytokine-stimulated RINm5F cells showed increased $\mathrm{NF}-\mathrm{\kappa B}$ binding activity (Figure $3 \mathrm{~A}$, lane 2 ), as well as increased nuclear levels of the p65 and p50 subunits (Figure $3 \mathrm{~B}$ ), as compared to unstimulated cells. In contrast, cytokine-induced NF-кB activation was markedly suppressed by sulfuretin pretreatment, suggesting that sulfuretin inhibited iNOS expression by suppressing NF-kB activation.

We previously reported that $I \kappa B \alpha$, but not $I \kappa B \beta$, was the major participant in cytokine-induced NF- $\mathrm{kB}$ activation (Kim et al., 2007a). Therefore, we investigated $I_{\kappa} B \alpha$ levels in the cytosol following cytokine treatment (Figure 3B). Cytokine-treated RINm5F cells showed a decreased level of $I \kappa B \alpha$ protein in the cytosol compared to a similar fraction from unstimulated cells; however, increased $I \kappa B \alpha$ degradation as a result of cytokine treatment was markedly suppressed by pretreatment with sulfuretin. 
A

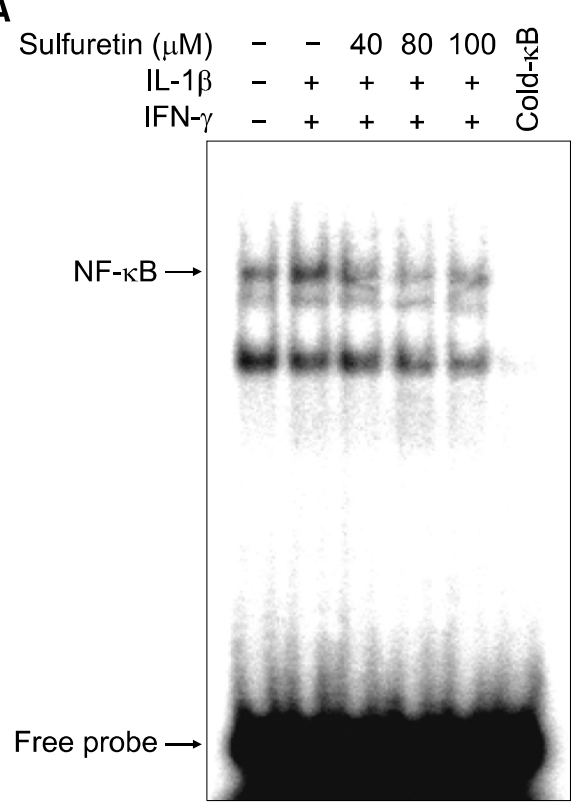

B

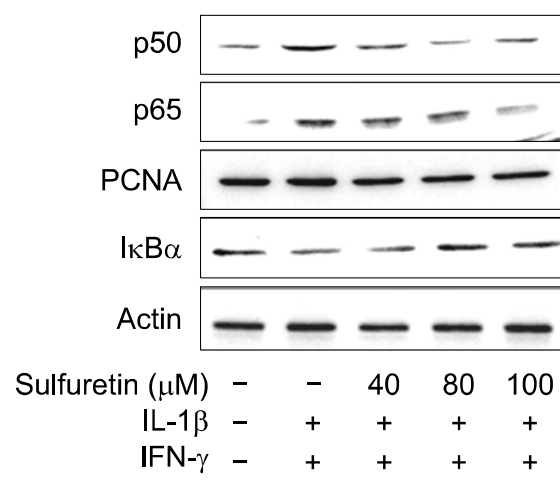

Figure 3. Sulfuretin inhibits cytokine-induced NF- $\kappa B$ activation in RINm5F cells. RINm5F cells were pretreated with the indicated concentrations of sulfuretin for $3 \mathrm{~h}$ and $\mathrm{IL}-1 \beta(1 \mathrm{U} / \mathrm{ml})$ and IFN- $\gamma(100 \mathrm{U} / \mathrm{ml})$ were added subsequently. After $1 \mathrm{~h}$, NF- $\kappa B$ DNA binding was analyzed by EMSA (A), and nuclear translocation of p65 and $p 50$ and $I_{\kappa} B \alpha$ degradation in the cytosol $(B)$ were determined by Western blotting. Actin and PCNA were used as loading controls for cytosolic and nuclear proteins, respectively.

\section{Sulfuretin suppressed the cytokine-induced NF-кB pathway and preserved glucose stimulated insulin secretion in rat islets}

We further assayed the preventive effects of sulfuretin using rat pancreatic islets isolated from male Sprague-Dawley rats. Incubation of rat islets with cytokine for $24 \mathrm{~h}$ resulted in a 2.7-fold increase in nitric oxide production (Figure 4A). Real time RT-PCR and Western blotting revealed that iNOS mRNA and protein levels were markedly increased by cytokine (Figure 4A). Consistent with results from RINm5F cells, pretreatment of islets with sulfuretin abolished the cytokine effects and reduced nitric oxide production and iNOS expression to the level of control islets. Additionally, treatment with cytokine increased NF- $\mathrm{B}$ DNA binding activity in islets (Figure $4 \mathrm{~B}$ ), and pretreatment of islets with sulfuretin almost completely abolished these effects. To add functional data, sulfuretin protection against cytokine-induced impairment of glucose stimulated insulin secretion was evaluated. After $24 \mathrm{~h}$ of cytokine exposure, insulin secretion was assayed in response to 20 $\mathrm{mM}$ glucose. Control islets secreted $15.1 \pm 1.3$ $\mathrm{ng} / \mathrm{ml}$ insulin, while cytokine-treated islets secreted significantly less, at $1.1 \pm 0.7 \mathrm{ng} / \mathrm{ml}(P<0.01)$ (Figure 4C). However, pretreatment with sulfuretin blocked the cytokine effect and maintained islet cell insulin secretion levels to those of the control. In addition, treatment with sulfuretin alone did not affect insulin secretion in response to glucose (data not shown).

\section{Sulfuretin had an anti-diabetic effect in mice}

Mice injected with streptozotocin gradually became hyperglycemic, with an increased incidence of diabetes observed starting at day 3 . At day 5 , the average blood glucose level of mice injected with streptozotocin was $502 \pm 29.0 \mathrm{mg} / \mathrm{dl}$ (Figure 5A). Mice pretreated with sulfuretin were fully resistant to diabetes development, and treatment with sulfuretin alone did not affect blood glucose concentration. In addition, the mean plasma insulin level at day 5 in the streptozotocin group decreased by $82.5 \%$ relative to the control (from $8.5 \pm 0.4 \mathrm{ng} / \mathrm{ml}$ to $1.8 \pm 0.2 \mathrm{ng} / \mathrm{ml}$ ), while the severity of hypoinsulinemia was attenuated in mice pretreated with sulfuretin (Figure 5A). These results indicate that sulfuretin is protective against streptozotocin-induced diabetes.

The preventative effect of sulfuretin on streptozotocin-induced diabetes was histologically examined. Pancreatic tissues at day 5 after streptozotocin administration, with or without sulfuretin pretreatment, were subjected to hematoxylin and eosin staining and immunohistochemistry. Streptozotocin-treated mice showed degenerative and necrotic changes and islet shrinkage (Figure 5B, b), as well as weak insulin-reactivity in few $\beta$-cells (Figure 5B, f). However, tissues from streptozotocin-treated mice pretreated with sulfuretin showed round, nearly normal, and clearly defined islets that were strongly positive for insulin (Figure $5 B$, $d$ and $h$ ).

To elucidate the antidiabetogenic mechanism of 
A
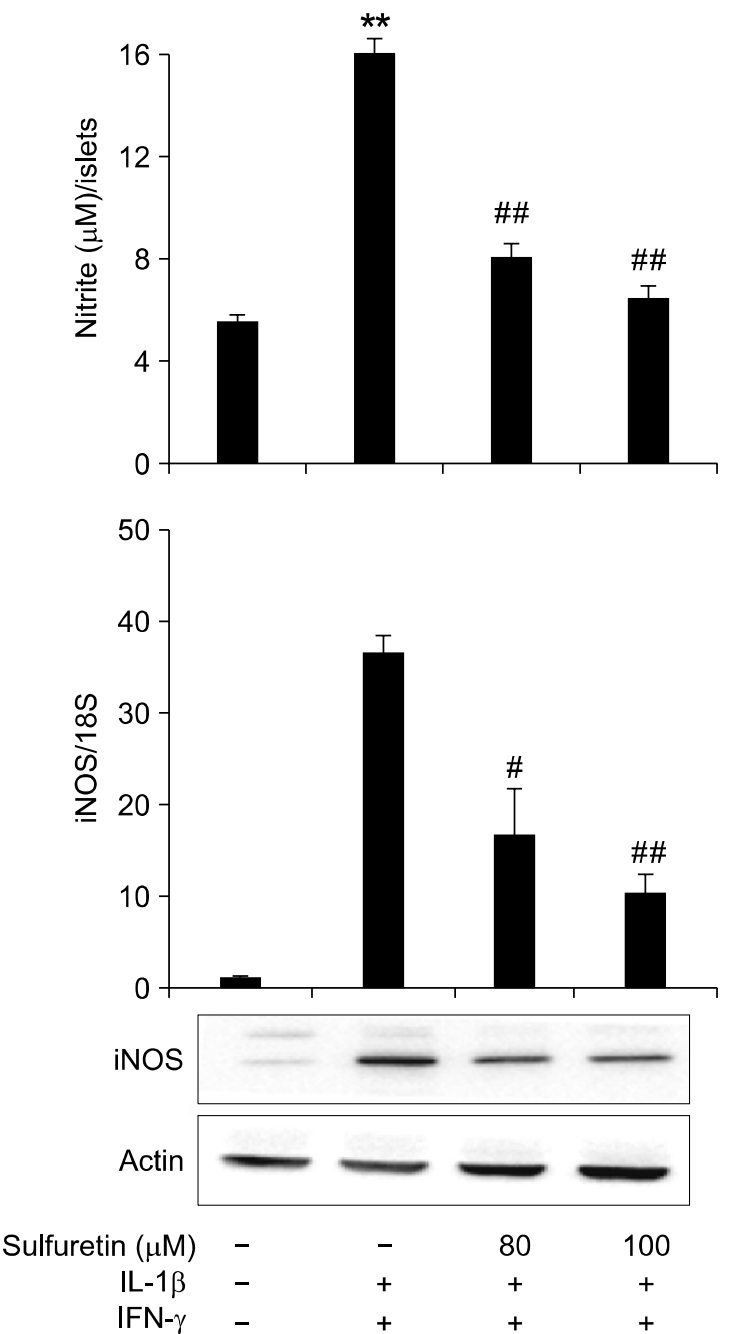

B

C

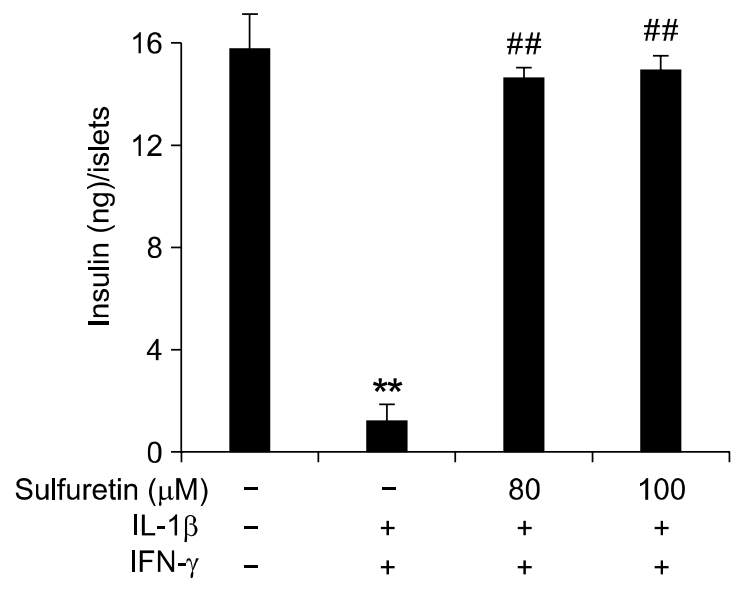

Figure 4. Sulfuretin inhibits cytokine-induced activation of the NF- $\mathrm{B}$ pathway and maintains glucose-stimulated insulin secretion in rat islets. Rat islets were treated with IL-1 $\beta(1 \mathrm{U} / \mathrm{ml})$ and IFN- $\gamma(100 \mathrm{U} / \mathrm{ml})$ with or without a 3-h pretreatment with the indicated concentrations of sulfuretin. Nitrite production

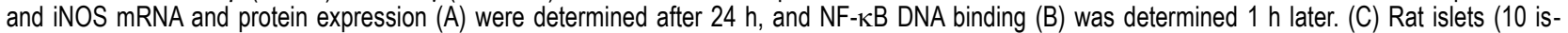
lets $/ 500 \mu \mathrm{l})$ were treated with $\mathrm{IL}-1 \beta(1 \mathrm{U} / \mathrm{ml})$ and IFN- $\gamma(100 \mathrm{U} / \mathrm{ml})$ with or without a 3-h pretreatment with the indicated concentrations of sulfuretin. Following $24 \mathrm{~h}$ incubation, glucose-stimulated insulin secretion was quantified. The results of triplicate samples are expressed as the mean \pm the SEM. ${ }^{* *} P<0.01$ vs. untreated control; ${ }^{\#} P<0.05,{ }^{\#} P<0.01$ vs. cytokine.

sulfuretin, we examined its effect on streptozotocin-induced NF- $\mathrm{B}$ a activation. Figure $5 \mathrm{C}$ is a representative electrophoretic mobility shift assay (EMSA) showing the ${ }^{32} \mathrm{P}-\mathrm{DNA} / \mathrm{NF}-\kappa \mathrm{B}$ complex formed with nuclear extracts from a pancreas 30 min after streptozotocin administration. The findings were similar to those of our previous study, with streptozotocin treatment resulting in increased $N F-\kappa B$ binding to DNA (Lv et al., 2009). This complex was not detected in pancreatic nuclear extracts from sulfuretin-pretreated mice. Taken together, these results show that sulfuretin inhibits $N F-\kappa B$ activation and prevents diabetes development in mice.

\section{Discussion}

In this study, we present, for the first time, a mode of action for sulfuretin protection against the diabetes development. Intraperitoneal administration of sulfuretin prevented diabetes development after streptozotocin treatment and preserved $\beta$-cell masses. In addition, sulfuretin protected $\beta$-cells from cytokine toxic challenge in RINm5F cells and islets.

One of the important pathogenetic mechanisms of pancreatic $\beta$-cell damage is associated with increased expression of proinflammatory cytokines, such as IL-1 $\beta$, IFN- $\gamma$, and TNF- $\alpha$. During 
A
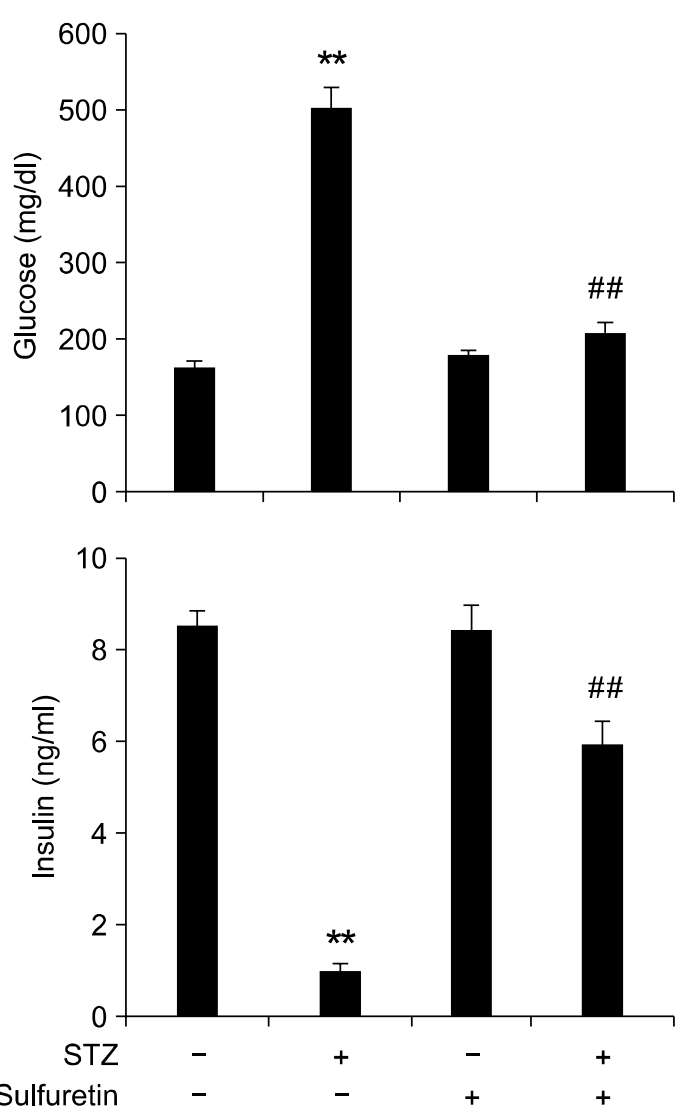

B
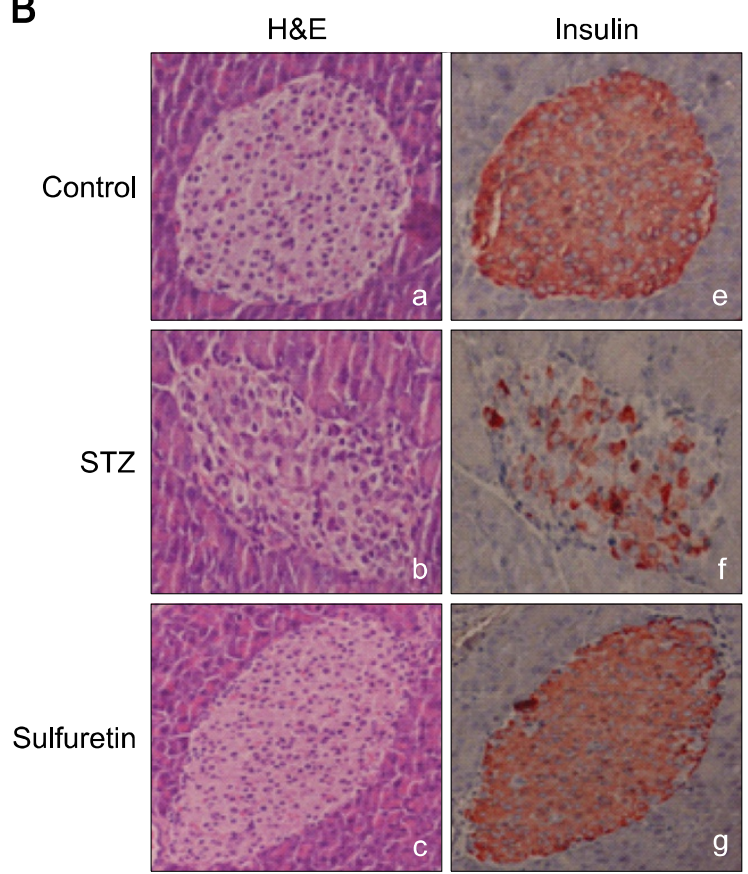

Sulfuretin

+ STZ
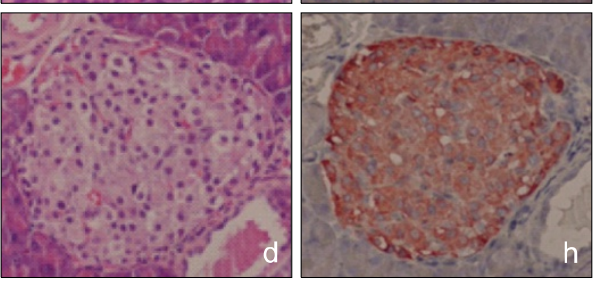

C

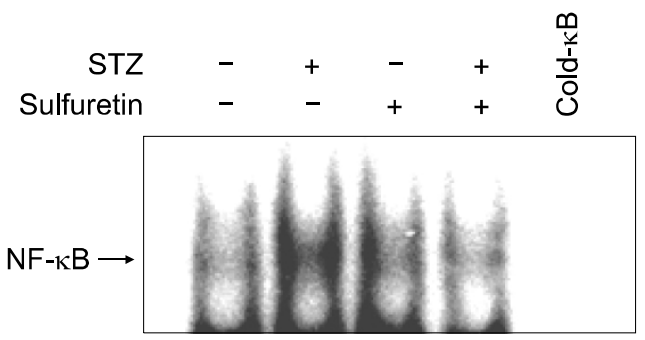

Figure 5. Sulfuretin protects islets from streptozotocin (STZ)-induced destruction. (A) ICR mice were intraperitoneally injected daily with sulfuretin at 40 $\mu \mathrm{g} / \mathrm{kg}$ for three days and then injected with streptozotocin $(80 \mathrm{mg} / \mathrm{kg}$ ) intravenously. Levels of fasting glucose and insulin were determined. (B) Pancreases were obtained from normal control $(a, e)$, streptozotocin-injected $(b, f)$, sulfuretin-injected $(c, g)$, and sulfuretin and streptozotocin-injected mice (d, h). Islets and adjoining exocrine regions were stained with hematoxylin and eosin (a-d). $\beta$-cells were labeled with insulin antibody and peroxidase-labeled anti-rabbit lgG (e-h). (C) Nuclear extracts from pancreatic tissues were prepared 30 min after streptozotocin injection, and DNA binding of NF- $\kappa B$ was analyzed using EMSA. ${ }^{* *} P<0.01$ vs. untreated control; ${ }^{\#} P<0.01$ vs. streptozotocin-injected group.

development of type 1 diabetes, TNF- $\alpha$ is secreted from infiltrated macrophages and induces production of several other inflammatory cytokines, including IL-1 $\beta$ (Hanafusa and Imagawa, 2008). Reportedly, a transcriptional TNF- $\alpha$ inhibitor prevents diabetes development in the streptozotocin-induced diabetes model (Holstad and Sandler, 2001). IL-1 $\beta$ has been implicated in early events in $\beta$-cell destruction. Suppression of IL-1 $\beta$ production or inhibition of its interaction with corresponding cellular receptors significantly inhibits IL-1 $\beta$-mediated deleterious effects on $\beta$ cells (Giannoukakis et al., 1999; Tellez et al., 2005). IL-1 $\beta$ exerts its main effects through $N F-\kappa B$ activation, iNOS expression, and nitric oxide production (Corbett and McDaniel, 1995; Arnush et 
al., 1998; Lee et al., 2009). IFN- $\gamma$ alone does not stimulate iNOS expression in rodent or human islets, but it reduces the concentration of $\mathrm{IL}-1 \beta$ required to induce iNOS expression in rat islets, and a combination of IL-1 $\beta$ and IFN- $\gamma$ is required to induce iNOS expression and $\beta$-cell dysfunction in mouse and human islets (Heitmeier et al., 1997). As has been shown previously by our group and others, treatment of insulinoma cells or isolated islets with cytokines adversely affected viability and insulin secretion in response to glucose (Giannoukakis et al., 1999; Karin and Lin, 2002; Kim et al., 2007b; Lee et al., 2009). Therefore, preventing the deleterious effects of proinflammatory cytokines is essential to preserve functional $\beta$-cell mass.

Most, but not all (Chang et al., 2003; Kim et al., 2007c), data show that activated NF-KB is detrimental in $\beta$-cells with respect to both viability and function. NF- $\kappa B$ regulates the expression of multiple proinflammatory genes, such as Fas (Darville and Eizirik, 2001), iNOS (Eizirik et al., 1996), and cyclooxygenase-2 (Sorli et al., 1998). In addition, the promoters of other proinflammatory genes induced in $\beta$-cells, including chemokines and adhesion molecules, also possess binding elements for NF-kB (May and Ghosh, 1998). The importance of NF- $\kappa B$ in $\beta$-cell damage is underscored by the fact that inhibition of NF- $\kappa B$ prevents cytokine-induced $\beta$-cell dysfunction and death in both in vitro and in vivo models (Heimberg et al., 2001; Mabley et al., 2002; Kim et al., 2007b). In contrast, the defensive and protective role of $N F-\kappa B$ is also reported. Blockage of $N F-\kappa B$ through an $I_{\kappa} \mathrm{B} \alpha$ super-repressor sensitizes $\beta$-cells to TNF- $\alpha$-mediated apoptosis (Chang et al., 2003). $\mathrm{NF}-\kappa \mathrm{B}$ regulates apoptosis by controlling the expression of multiple antiapoptotic genes, including the inhibitor of apoptosis protein (IAP) and A20/tumor necrosis factor (TNF)-induced protein 3 (TNFAIP3) (Karin and Lin, 2002; Liuwantara et al., 2006). Recently, Kim et al. (2007c) reported that $N F-\kappa B$ had an antiapoptotic function in $\beta$-cells incubated with a combination of TNF- $\alpha$ and IFN- $\gamma$ and showed a proapoptotic effect in $\beta$-cells treated with IL-1 $\beta$ and IFN- $\gamma$, similar to our results. Therefore, NF-kB governs both cell death and survival responses according to the modes of insult in $\beta$-cells. In this model, sulfuretin completely inhibited nitric oxide production in $\mathrm{IL}-1 \beta$ and IFN- $\gamma$-treated RINm5F cells and islets, through suppression of NF-kB-dependent iNOS expression, thereby protecting RINm5F cells and islets from cytokine cytotoxicity. In addition to increased cell viability, we observed preservation of insulin secretion in sulfuretin pre-treated rat islets. The molecular mechanism by which sulfuretin inhibits NF- $\kappa \mathrm{B}$ activation against cytokines appears to involve both inhibition of $1 \kappa \mathrm{B} \alpha$ degradation and translocation of p65 and p50 into the nucleus. Such an effect has also been shown with other polyphenolic compounds, such as epicathechin (Kim et al., 2004), genistein (Kim et al., 2007b), curcumin (Kanitkar et al., 2008), guggulsterone (Lv et al., 2008), resveratrol (Lee et al., 2009), and sulforaphane (Song et al., 2009).

Sulfuretin not only protected RINm5F cells and rat islets against cytokine toxicity, but also protected against streptozotocin-induced diabetes. Streptozotocin destroys islet cells through several mechanisms, including the production of reactive oxygen species (ROS) (Takasu et al., 1991),

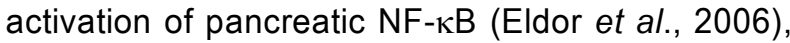
and induction of pronounced immune and inflammatory responses (Iwakiri et al., 1990). In addition, streptozotocin itself is a nitric oxide donor and liberates this nitrosative species during its intracellular metabolism (Kwon, et al., 1994). Streptozotocin-induced diabetic mice were previously reported to show increased $N F-\kappa B$ activity and iNOS expression in islets at a very early stage ( $\mathrm{Ho}$ et al., 2000; Lv et al., 2009). In this situation, generated nitric oxide may react with ROS, like the superoxide anion, to form highly oxidizing peroxynitrite, which would lead to more aggressive oxidative and nitrosative stress. In this study, streptozotocin-injected mice showed marked islet destruction and relatively small numbers of insulin-positive $\beta$-cells, while sulfuretin pre-treated mice showed well-defined islets and strong insulin-positive staining. An EMSA revealed increased $N F-\kappa B$ binding activity in pancreatic nuclear extracts derived from streptozotocin-injected hyperglycemic diabetic mice. However, pretreatment with sulfuretin prevented $\mathrm{NF}-\kappa \mathrm{B}$ activation, resulting in the maintenance of plasma glucose and insulin levels in the normal range.

Alternatively, the sulfuretin's anti-diabetic effect may be related to its anti-oxidative properties. The generation of ROS is another important mechanism of cytokine- and other diabetogenic drug-mediated toxicities in $\beta$-cells. Experimental evidences indicate that ROS are generated in both cytokine-stimulated (Sumoski et al., 1989; Suarez-Pinzon et al., 1997) and STZ-treated $\beta$-cells (Oberley, 1988 ), and that the overexpression of antioxidant enzymes protects $\beta$-cells from such insults (Tiedge et al., 1997; Lortz et al., 2000). Furthermore, ROS induce NF- $\kappa$ B activation and iNOS expression in rodent and human $\beta$-cells (Bedoya et al., 1995; Flodstrom et al., 1995), which suggests a role for ROS in the pathway of NF- $\kappa$ B activation and iNOS 
expression induced by cytokines. Studies have confirmed that sulfuretin-rich $R$. verniciflua is effective in reducing oxidative stress (Lee et al., 2002) and that ROS induces NF-kB activation (Adcock et al., 1994; Schmidt et al., 1995), suggesting that the ROS-scavenging effect of sulfuretin might suppress cytokine- or streptozotocin-induced NF-kB activation. Taken together, these results suggest that manipulation of NF-kB activity by sulfuretin in pancreatic $\beta$-cells allows these cells to withstand and survive cytokine- and streptozotocin-mediated toxicities.

In summary, this study is the first to demonstrate that sulfuretin has a $\beta$-cell protective effect. Specifically, sulfuretin protected $\beta$-cells from cytokine-induced injury in vitro and counteracted the diabetes development in response to streptozotocin in vivo. This $\beta$-cell protective effect may be mediated, at least in part, by suppressing NF- $\mathrm{kB}$ activation.

\section{Methods}

\section{Cell culture and reagents}

Rat pancreatic $\beta$-cell line RINm5F cells were obtained from the American Type Culture Collection and were grown at $37^{\circ} \mathrm{C}$ in a humidified $5 \% \mathrm{CO}_{2}$ atmosphere. RPMI 1640 medium (Gibco BRL, Grand Island, NY), supplemented with $10 \%$ FBS and $2 \mathrm{mM}$ glutamine, 100 units/ml penicillin, $100 \mu \mathrm{g} / \mathrm{ml}$ streptomycin, and $2.5 \mu \mathrm{g} / \mathrm{ml}$ amphotericin B, was used. IL-1 $\beta$ and IFN- $\gamma$ were obtained from R\&D Systems (Minneapolis, MN). All reagents were from Sigma (St. Louis, MO), unless otherwise noted.

\section{Plant materials and isolation of sulfuretin}

The heartwood of $R$. verniciflua was purchased from a standard commercial source (Omni Herb, Seoul, Korea), and its identity was confirmed at the Korean Drug Test Laboratory (Seoul, Korea). The voucher specimen (WK-2009-42) was deposited at the Herbarium in the College of Pharmacy, Wonkwang University. Dried heartwood of $R$. verniciflua $(1 \mathrm{~kg})$ was extracted twice with hot methanol (1:I) for $2 \mathrm{~h}$. The methanol extract $(37.78 \mathrm{~g})$ was dissolved in water (1:I) and partitioned with $n$-hexane (1:I) and ethyl acetate (1:I). The ethyl acetate-soluble fraction $(8.71 \mathrm{~g})$ was chromatographed on a silica gel column $(6.5$ $\times 60 \mathrm{~cm})$ using $n$-hexane/acetone $(3: 1)$ as the eluent to obtain two fractions (Fraction A and B). Fraction B (660 $\mathrm{mg}$ ) was chromatographed on a reverse-phase MPLC (column: ODS-S-50 B, $120 \AA$, $50 \mu \mathrm{m}$ ) eluted with $50 \%$ aqueous methanol to give sulfuretin $(550 \mathrm{mg}, 0.055 \mathrm{w} / \mathrm{w}$ $\%)$. Pure sulfuretin forms an amorphous yellow powder with a melting point of $280-285^{\circ} \mathrm{C}$. The spectral data were identical to those of our previous report (Jung et al., 2003): ${ }^{1} \mathrm{H}-\mathrm{NMR}\left(500 \mathrm{MHz}, \mathrm{CD}_{3} \mathrm{OD}\right) \delta: 7.50(1 \mathrm{H}, d, J=8.25 \mathrm{~Hz}$, $\mathrm{H}-4), 7.42\left(1 \mathrm{H}\right.$, br s, H-2'), $7.13\left(1 \mathrm{H}, d, J=7.3 \mathrm{~Hz}, \mathrm{H}-6^{\prime}\right)$, $6.74\left(1 \mathrm{H}, d, J=8.25 \mathrm{~Hz}, \mathrm{H}-5{ }^{\prime}\right), 6.62-6.58(3 \mathrm{H}, m, \mathrm{H}-5, \mathrm{H}-7$,
$\mathrm{H}-10) ;{ }^{13} \mathrm{C}-\mathrm{NMR}\left(125 \mathrm{MHz}, \mathrm{CD}_{3} \mathrm{OD}\right) \delta: 183.1$ (C-3), 168.5 (C-6), 167.2 (C-8), 148.0 (C-4'), 146.4 (C-2), 145.4 (C-3'), 125.5 (C-4), 125.0 (C-6'), 124.2 (C-1'), 117.6 (C-2'), 115.3 (C-5'), 113.4 (C-9), 113.3 (C-10), 112.8 (C-7), 98.0 (C-5); (-)-ESI-MS m/z: 269 [M-H].

\section{HPLC analysis of sulfuretin}

A $20-\mu$ l aliquot of the sulfuretin solution $(5 \mathrm{mg} / \mathrm{ml}$ in methanol) was analyzed by an inertsil ODS-3 column (4.6 $\times 150 \mathrm{~mm}, 5 \mathrm{~mm}$, GL Sciences, Tokyo, Japan) using the SYKAM HPLC system (Eresing, Germany) equipped with a model S2100 solvent delivery system, S7131 reagent organizer, S5200 injector and S3210 UV/Vis multidiode array detector controlled by Chromstar software (version 6.03.23, SCPA, Weyhe-Leeste, Germany). HPLC analyses were performed at a flow rate of $1.0 \mathrm{ml} / \mathrm{min}$ with a linear gradient from 30 to $70 \%$ acetonitrile in water for $40 \mathrm{~min}$.

\section{MTT assay for cell viability}

Cultured cell viability was determined by the reduction of MTT to formazan. RINm5F cells were seeded overnight in clear, flat-bottomed 96-well tissue culture plates at $10^{5}$ cells/well in $100 \mu \mathrm{l}$ medium. Cells were pretreated with sulfuretin for $3 \mathrm{~h}$; then IL-1 $\beta(1 \mathrm{U} / \mathrm{ml})$ and IFN- $\gamma(100 \mathrm{U} / \mathrm{ml})$ were added for an additional $48 \mathrm{~h}$. Cells were washed twice with PBS, and MTT was added (100 $\mu \mathrm{g} / 100 \mu \mathrm{l} \mathrm{PBS})$. After incubation at $37^{\circ} \mathrm{C}$ for $1 \mathrm{~h}, 100 \mu \mathrm{LMSO}$ was added to dissolve the formazan crystals, and absorbance was measured at $570 \mathrm{~nm}$ using a Spectra MAX PLUS spectrophotometer (Molecular Devices, Sunnyvale, CA).

\section{Nitric oxide measurement}

Biologically produced nitric oxide is rapidly oxidized to nitrite and nitrate in aqueous solution. As such, nitric oxide production was measured as nitrite concentration in cell-free culture supernatants using a colorimetric assay. Briefly, $5 \times 10^{5}$ RINm5F cells or 100 islet samples were pretreated with the indicated concentrations of sulfuretin for $3 \mathrm{~h}$ prior to the addition of IL-1 $\beta(1 \mathrm{U} / \mathrm{ml})$ and IFN- $\gamma(100$ $\mathrm{U} / \mathrm{ml})$. After $24 \mathrm{~h}, 100 \mu \mathrm{l}$ aliquots of culture supernatant were incubated with $100 \mu \mathrm{l}$ of a modified Griess reagent, $(1: 1$ mixture of $1 \%$ sulfanilamide in $30 \%$ acetic acid and $0.1 \% \mathrm{~N}$-(1-naphthyl) ethylenediamine dihydrochloride in $60 \%$ acetic acid), at room temperature for $5 \mathrm{~min}$, and the absorbance was measured at $540 \mathrm{~nm}$ using a spectrophotometer. Nitric oxide concentration was determined from a linear standard curve of sodium nitrite serial dilutions in a working medium.

\section{Whole cell and nuclear protein extracts}

Cells, islets, or pancreatic tissues were washed with PBS and lysed in CytoBuster Protein Extraction Reagent (Novagen, Madison, WI). The lysate was centrifuged at $10,000 \times g$ for 5 min at $4^{\circ} \mathrm{C}$, and the supernatant was used as the whole cell protein extract. Cytosolic and nuclear extracts were prepared from cells using NE-PER Nuclear and Cytoplasmic Extraction Reagents (Pierce 
Biotechnology, Rockford, IL).

\section{Western blot analysis}

RINm5F cells $\left(5 \times 10^{6}\right)$ or 30 islet samples were homogenized in $100 \mu \mathrm{l}$ ice-cold lysis buffer $(20 \mathrm{mM}$ HEPES, pH 7.2, 1\% Triton X-100, 10\% glycerol, $1 \mathrm{mM}$ PMSF, $10 \mu \mathrm{g} / \mathrm{ml}$ leupeptin, $10 \mu \mathrm{g} / \mathrm{ml}$ aprotinin). Protein (20 $\mu \mathrm{g})$ was separated by SDS-PAGE and transferred to nitrocellulose membranes. Blots were probed with $1 \mu \mathrm{g} / \mathrm{ml}$ primary antibody against $\mathrm{p} 50, \mathrm{p} 65$, iNOS, $I \kappa B \alpha$, actin, or PCNA (Santa Cruz Biochemicals, Santa Cruz, CA) and detected with horseradish peroxidase-conjugated IgG (Zymed, South San Francisco, CA).

\section{EMSA}

NF- $\kappa \mathrm{B}$ activation was assayed using a gel mobility shift assay with nuclear extracts from control and treated cells. An oligonucleotide containing the $\kappa$-chain binding site $(\kappa B$, 5'-CCGGTTAACAGAGGGGGCTTTCCGAG-3') was used as a probe. The two complementary strands were annealed and labeled with $\left[\alpha-{ }^{32} \mathrm{P}\right] \mathrm{dCTP}$. Comprising the binding reaction mixture, labeled oligonucleotide $(10,000$ $\mathrm{cpm}), 10 \mu \mathrm{g}$ nuclear extract protein, and binding buffer (10 $\mathrm{mM}$ Tris- $\mathrm{HCl}, \mathrm{pH} 7.6,500 \mathrm{mM} \mathrm{KCl}, 10 \mathrm{mM}$ EDTA, $50 \%$ glycerol, $100 \mathrm{ng}$ poly(dl·dC), $1 \mathrm{mM}$ DTT) were mixed in a final volume of $20 \mu \mathrm{l}$ and incubated for $30 \mathrm{~min}$ at room temperature. Reactions were separated on $4 \%$ polyacrylamide gels in $0.5 \times$ Tris-borate buffer, and the gels were dried and visualized by autoradiography. Specificity of the DNA-NF-kB interaction was demonstrated by competitive assays using a 50 -fold excess of unlabeled oligonucleotide.

\section{RNA isolation and real time RT-PCR}

RNA was isolated from RINm5F cells or islets using Trizol reagent (Invitrogen, Carlsbad, CA). RNA was precipitated with isopropanol and dissolved in DEPC-treated distilled water. Total RNA $(2 \mu \mathrm{g})$ was treated with RNase-free DNase (Invitrogen, Carlsbad, CA), and first-strand cDNA was generated using a random hexamer primer supplied in a first-strand cDNA synthesis kit (Applied Biosystems, Foster City, CA). Specific primers for iNOS were designed using primer express software (Applied Biosystems): iNOS (accession No. NM_012611), 5'-TGTGCTAATGCGGAAGGTCAT-3' (forward), and 5'-CGACTTTCCTGTCTCAGTAGCAAA-3' (reverse). Control 18S ribosomal RNA was purchased from Applied Biosystems and was used as the invariant control. Real-time RT-PCR mixtures consisted of $10 \mathrm{ng}$ reverse transcribed total RNA, $167 \mathrm{nM}$ forward and reverse primers, and $2 \times \mathrm{PCR}$ master mixture in a final volume of $10 \mu \mathrm{l}$. Reactions were performed in 384-well plates using the ABI Prism 7900HT Sequence Detection System (Applied Biosystems, Foster City, CA). All experiments were performed in triplicate.

\section{Glucose-stimulated insulin secretion assay}

Pancreatic islets were isolated from male Sprague-Dawley rats using the collagenase digestion method (Kim et al., 2007a). Islets were cultured for $24 \mathrm{~h}$ with IL-1 $\beta$ and IFN- $\gamma$ in the presence or absence of sulfuretin, and subsequently washed three times in Krebs-Ringer bicarbonate buffer (25 $\mathrm{mM}$ HEPES, $115 \mathrm{mM} \mathrm{NaCl}, 24 \mathrm{mM} \mathrm{NaHCO}, 5 \mathrm{mM} \mathrm{KCl}, 1$ $\mathrm{mM} \mathrm{MgCl} 2,2.5 \mathrm{mM} \mathrm{CaCl}_{2}, 0.1 \%$ bovine serum albumin, $\mathrm{pH}$ 7.4) containing $3 \mathrm{mM}$ D-glucose. Insulin secretion assays were performed with either 5.5 or $20 \mathrm{mM}$ D-glucose. All experiments were performed in triplicate.

\section{Type 1 diabetes induction}

Specific pathogen-free male ICR mice were purchased from Orientbio Inc. (Seoungnam, Korea) and acclimated to our animal facility for one week. All mice were kept under specific pathogen-free conditions with free access to a standard commercial diet and were used at 5-6 weeks of age. To induce diabetes, mice were injected via the tail vein with $80 \mathrm{mg} / \mathrm{kg}$ body weight streptozotocin dissolved in $0.1 \mathrm{M}$ sodium citrate buffer ( $\mathrm{pH} 4.0)$, prepared within 5 min of administration. Mice were divided into the following groups: 1) non-treated controls, 2) streptozotocin, 3) sulfuretin, and 4) sulfuretin + streptozotocin ( $n=5$ for each group). Control animals received citrate buffer alone. Group 4 received intraperitoneal injections of $40 \mu \mathrm{g} / \mathrm{kg}$ sulfuretin daily for three days before administration of streptozotocin. The day on which streptozotocin was first administered was defined as day 1 . At day 5 , mice were sacrificed by decapitation without anesthesia, and trunk blood was collected in pre-chilled tubes containing $1 \mathrm{mg} / \mathrm{ml}$ EDTA. Plasma glucose was assayed using the glucose oxidase method (Sigma, St. Louis, MO), and plasma insulin was measured using a radioimmunoassay kit (Linco Research, St. Charles, MO). All experimental procedures were approved by the Institutional Animal Care and Use Committee at Chonbuk National University.

\section{Immunohistochemistry}

Immunohistochemical staining was performed using the DAKO Envision system (DAKO, Carpinteria, CA), which uses dextran polymers conjugated with horseradish peroxidase to avoid contamination with endogenous biotin. Each pancreas was removed and immediately placed in fixative $(10 \%$ formalin solution in $0.1 \mathrm{M}$ PBS). Histological sections $(4 \mu \mathrm{m})$ were cut from formalin-fixed paraffin-embedded tissue blocks. After deparaffinization, tissue sections were treated using a microwave antigen retrieval procedure in $0.01 \mathrm{M}$ sodium citrate buffer. After blocking endogenous peroxidase, the sections were incubated with Protein Block Serum-Free (DAKO) to block nonspecific staining and then with anti-insulin antibody (Santa Cruz Biochemicals). Peroxidase activity was detected with 3-amino-9-ethyl carbazole.

\section{Statistical analysis}

Statistical analyses were performed using ANOVA and Duncan's tests. Differences with a $P<0.05$ were considered statistically significant. 


\section{Acknowledgements}

This work was supported by the Ministry of Science \& Technology (MoST)/Korea Science \& Engineering Foundation (KOSEF) through the Diabetes Research Center at Chonbuk National University (2010-0029463), by a research fund of Chonbuk National University in 2009 (to BHP), and by the National Research Foundation of Korea Grant funded by the Korean Government (NRF-2010355-C00037).

\section{References}

Adcock IM, Brown CR, Kwon O, Barnes PJ. Oxidative stress induces NFKB DNA binding and inducible NOS mRNA in human epithelial cells. Biochem Biophys Res Commun 1994;199:1518-24

Arnush M, Heitmeier MR, Scarim AL, Marino MH, Manning PT, Corbett JA. IL-1 produced and released endogenously within human islets inhibits $\beta$ cell function. $\mathrm{J}$ Clin Invest 1998;102:516-26

Bedoya FJ, Flodstrom M, Eizirik DL. Pyrrolidine dithiocarbamate prevents IL-1-induced nitric oxide synthase mRNA, but not superoxide dismutase mRNA, in insulin producing cells. Biochem Biophys Res Commun 1995; 210:816-22

Chang I, Kim S, Kim JY, Cho N, Kim YH, Kim HS, Lee MK, $\mathrm{Kim} \mathrm{KW}$, Lee MS. Nuclear factor $\kappa \mathrm{B}$ protects pancreatic $\beta$-cells from tumor necrosis factor- $\alpha$-mediated apoptosis. Diabetes 2003;52:1169-75

Cnop M, Welsh N, Jonas JC, Jorns A, Lenzen S, Eizirik DL. Mechanisms of pancreatic $\beta$-cell death in type 1 and type 2 diabetes: many differences, few similarities. Diabetes 2005;54 Suppl 2:S97-107

Corbett JA, McDaniel ML. Does nitric oxide mediate autoimmune destruction of $\beta$-cells? Possible therapeutic interventions in IDDM. Diabetes 1992;41:897-903

Corbett JA, McDaniel ML. Intraislet release of interleukin 1 inhibits $\beta$ cell function by inducing $\beta$ cell expression of inducible nitric oxide synthase. J Exp Med 1995;181:559-68

Corbett JA, McDaniel ML. The use of aminoguanidine, a selective iNOS inhibitor, to evaluate the role of nitric oxide in the development of autoimmune diabetes. Methods 1996; 10:21-30

Darville MI, Eizirik DL. Cytokine induction of Fas gene expression in insulin-producing cells requires the transcription factors NF-KB and C/EBP. Diabetes 2001;50:1741-8

Eizirik DL, Colli ML, Ortis F. The role of inflammation in insulitis and $\beta$-cell loss in type 1 diabetes. Nat Rev Endocrinol 2009;5:219-26

Eizirik DL, Flodstrom M, Karlsen AE, Welsh N. The harmony of the spheres: inducible nitric oxide synthase and related genes in pancreatic $\beta$ cells. Diabetologia 1996;39:875-90

Eldor R, Yeffet A, Baum K, Doviner V, Amar D, Ben-Neriah Y, Christofori G, Peled A, Carel JC, Boitard C, Klein T, Serup $\mathrm{P}$, Eizirik DL, Melloul D. Conditional and specific NF-кB blockade protects pancreatic $\beta$ cells from diabetogenic agents. Proc Natl Acad Sci USA 2006;103:5072-7

Flodstrom M, Niemann A, Bedoya FJ, Morris SM Jr, Eizirik $D L$. Expression of the citrulline-nitric oxide cycle in rodent and human pancreatic $\beta$-cells: induction of argininosuccinate synthetase by cytokines. Endocrinology 1995;136:3200-6

Giannoukakis N, Rudert WA, Ghivizzani SC, Gambotto A, Ricordi C, Trucco M, Robbins PD. Adenoviral gene transfer of the interleukin-1 receptor antagonist protein to human islets prevents IL-1 $\beta$-induced $\beta$-cell impairment and activation of islet cell apoptosis in vitro. Diabetes 1999; 48:1730-6

Hanafusa T, Imagawa A. Insulitis in human type 1 diabetes. Ann N Y Acad Sci 2008;1150:297-9

Heimberg H, Heremans Y, Jobin C, Leemans R, Cardozo AK, Darville M, Eizirik DL. Inhibition of cytokine-induced NF-kB activation by adenovirus-mediated expression of a NF-kB super-repressor prevents $\beta$-cell apoptosis. Diabetes 2001; 50:2219-24

Heitmeier MR, Scarim AL, Corbett JA. Interferon- $\gamma$ increases the sensitivity of islets of Langerhans for inducible nitric-oxide synthase expression induced by interleukin 1 . J Biol Chem 1997;272:13697-704

Ho E, Chen G, Bray TM. $\alpha$-phenyl-tert-butylnitrone (PBN) inhibits NFKB activation offering protection against chemically induced diabetes. Free Radic Biol Med 2000;28:604-14

Holstad M, Sandler S. A transcriptional inhibitor of TNF- $\alpha$ prevents diabetes induced by multiple low-dose streptozotocin injections in mice. J Autoimmun 2001;16:441-7

Iwakiri R, Nagafuchi S, Kounoue E, Nakamura M, Kikuchi M, Nakano S, Niho Y. Immunohistochemical study of insulitis induced by multiple low doses of streptozocin in CD-1 mice. Diabetes Res Clin Pract 1990;9:75-82

Jeon WK, Lee JH, Kim HK, Lee AY, Lee SO, Kim YS, Ryu SY, Kim SY, Lee YJ, Ko BS. Anti-platelet effects of bioactive compounds isolated from the bark of Rhus verniciflua Stokes. J Ethnopharmacol 2006;106:62-9

Jung $\mathrm{CH}$, Kim JH, Hong MH, Seog HM, Oh SH, Lee PJ, Kim GJ, Kim HM, Um JY, Ko SG. Phenolic-rich fraction from Rhus verniciflua Stokes (RVS) suppress inflammatory response via NF-KB and JNK pathway in lipopolysaccharide-induced RAW 264.7 macrophages. J Ethnopharmacol 2007;110: 490-7

Jung MJ, Chung HY, Kang SS, Choi JH, Bae KS, Choi JS. Antioxidant activity from the stem bark of Albizzia julibrissin. Arch Pharm Res 2003;26:458-62

Kanitkar M, Gokhale K, Galande S, Bhonde RR. Novel role of curcumin in the prevention of cytokine-induced islet death in vitro and diabetogenesis in vivo. $\mathrm{Br} \mathrm{J}$ Pharmacol 2008; 155:702-13

Karin M, Lin A. NF- $\kappa B$ at the crossroads of life and death. Nat Immunol 2002;3:221-7

Kim EK, Kwon KB, Koo BS, Han MJ, Song MY, Song EK, Han MK, Park JW, Ryu DG, Park BH. Activation of peroxisome 
proliferator-activated receptor- $\gamma$ protects pancreatic $\beta$-cells from cytokine-induced cytotoxicity via NFKB pathway. Int J Biochem Cell Biol 2007a;39:1260-75

Kim EK, Kwon KB, Song MY, Seo SW, Park SJ, Ka SO, Na L, Kim KA, Ryu DG, So HS, Park R, Park JW, Park BH. Genistein protects pancreatic $\beta$ cells against cytokine-mediated toxicity. Mol Cell Endocrinol 2007b;278:18-28

Kim MJ, Ryu GR, Kang JH, Sim SS, Min DS, Rhie DJ, Yoon SH, Hahn SJ, Jeong IK, Hong KJ, Kim MS, Jo YH. Inhibitory effects of epicatechin on interleukin-1 $\beta$-induced inducible nitric oxide synthase expression in RINm5F cells and rat pancreatic islets by down-regulation of NF- $\kappa B$ activation. Biochem Pharmacol 2004;68:1775-85

Kim S, Millet I, Kim HS, Kim JY, Han MS, Lee MK, Kim KW, Sherwin RS, Karin M, Lee MS. NF-KB prevents $\beta$ cell death and autoimmune diabetes in NOD mice. Proc Natl Acad Sci USA 2007c;104:1913-8

Kwon NS, Lee SH, Choi CS, Kho T, Lee HS. Nitric oxide generation from streptozotocin. FASEB J 1994;8:529-33

Lee JC, Lim KT, Jang YS. Identification of Rhus verniciflua Stokes compounds that exhibit free radical scavenging and anti-apoptotic properties. Biochim Biophys Acta 2002;1570: $181-91$

Lee JH, Song MY, Song EK, Kim EK, Moon WS, Han MK, Park JW, Kwon KB, Park BH. Overexpression of SIRT1 protects pancreatic $\beta$-cells against cytokine toxicity by suppressing the nuclear factor-kB signaling pathway. Diabetes 2009; 58:344-51

Liuwantara D, Elliot M, Smith MW, Yam AO, Walters SN, Marino E, McShea A, Grey ST. Nuclear factor- $\kappa B$ regulates $\beta$-cell death: a critical role for $A 20$ in $\beta$-cell protection. Diabetes 2006;55:2491-501

Lortz S, Tiedge M, Nachtwey T, Karlsen AE, Nerup J, Lenzen $\mathrm{S}$. Protection of insulin-producing RINm5F cells against cytokine-mediated toxicity through overexpression of antioxidant enzymes. Diabetes 2000;49:1123-30

Lv N, Song MY, Kim EK, Park JW, Kwon KB, Park BH. Guggulsterone, a plant sterol, inhibits NF- $\kappa B$ activation and protects pancreatic $\beta$ cells from cytokine toxicity. Mol Cell Endocrinol 2008;289:49-59

Lv N, Song MY, Lee YR, Choi HN, Kwon KB, Park JW, Park $\mathrm{BH}$. Dihydroavenanthramide $\mathrm{D}$ protects pancreatic $\beta$-cells from cytokine and streptozotocin toxicity. Biochem Biophys Res Commun 2009;387:97-102

Mabley JG, Hasko G, Liaudet L, Soriano F, Southan GJ, Salzman AL, Szabo C. NFKB1 (p50)-deficient mice are not susceptible to multiple low-dose streptozotocin-induced diabetes. J Endocrinol 2002;173:457-64

May MJ, Ghosh S. Signal transduction through NF-kB. Immunol Today 1998;19:80-8

Melloul D. Role of NF-кB in $\beta$-cell death. Biochem Soc Trans 2008;36:334-9

Oberley LW. Free radicals and diabetes. Free Radic Biol Med

\section{8;5:113-24}

Papaccio G. Insulitis and islet microvasculature in type 1 diabetes. Histol Histopathol 1993;8:751-9

Park KY, Jung GO, Lee KT, Choi J, Choi MY, Kim GT, Jung $\mathrm{HJ}$, Park HJ. Antimutagenic activity of flavonoids from the heartwood of Rhus verniciflua. J Ethnopharmacol 2004;90: 73-9

Pasparakis M. Regulation of tissue homeostasis by NF-kB signalling: implications for inflammatory diseases. Nat Rev Immunol 2009;9:778-88

Schmidt KN, Amstad P, Cerutti P, Baeuerle PA. The roles of hydrogen peroxide and superoxide as messengers in the activation of transcription factor NF-кB. Chem Biol 1995; 2:13-22

Song MY, Kim EK, Moon WS, Park JW, Kim HJ, So HS, Park $\mathrm{R}$, Kwon KB, Park BH. Sulforaphane protects against cytokine- and streptozotocin-induced $\beta$-cell damage by suppressing the NF-кB pathway. Toxicol Appl Pharmacol 2009;235:57-67

Sorli $\mathrm{CH}$, Zhang HJ, Armstrong MB, Rajotte RV, Maclouf J, Robertson RP. Basal expression of cyclooxygenase-2 and nuclear factor-interleukin 6 are dominant and coordinately regulated by interleukin 1 in the pancreatic islet. Proc Natl Acad Sci USA 1998;95:1788-93

Stadler J, Billiar TR, Curran RD, Stuehr DJ, Ochoa JB, Simmons RL. Effect of exogenous and endogenous nitric oxide on mitochondrial respiration of rat hepatocytes. Am J Physiol 1991;260:C910-6

Suarez-Pinzon WL, Szabo C, Rabinovitch A. Development of autoimmune diabetes in NOD mice is associated with the formation of peroxynitrite in pancreatic islet $\beta$-cells. Diabetes 1997;46:907-11

Sumoski W, Baquerizo H, Rabinovitch A. Oxygen free radical scavengers protect rat islet cells from damage by cytokines. Diabetologia 1989;32:792-6

Szkudelski T. The mechanism of alloxan and streptozotocin action in B cells of the rat pancreas. Physiol Res 2001; 50:537-46

Takasu N, Komiya I, Asawa T, Nagasawa Y, Yamada T. Streptozocin- and alloxan-induced $\mathrm{H}_{2} \mathrm{O}_{2}$ generation and DNA fragmentation in pancreatic islets. $\mathrm{H}_{2} \mathrm{O}_{2}$ as mediator for DNA fragmentation. Diabetes 1991;40:1141-5

Tellez N, Montolio M, Biarnes M, Castano E, Soler J, Montanya E. Adenoviral overexpression of interleukin-1 receptor antagonist protein increases $\beta$-cell replication in rat pancreatic islets. Gene Ther 2005;12:120-8

Tiedge M, Lortz S, Drinkgern J, Lenzen S. Relation between antioxidant enzyme gene expression and antioxidative defense status of insulin-producing cells. Diabetes 1997; 46:1733-42

Yamamoto $\mathrm{H}$, Uchigata $\mathrm{Y}$, Okamoto $\mathrm{H}$. Streptozotocin and alloxan induce DNA strand breaks and poly(ADP-ribose) synthetase in pancreatic islets. Nature 1981;294:284-6 